\title{
Judean Pillar Figurines and Ethnic Identity in the Shadow of Assyria*
}

\author{
IAN DOUGLAS WILSON \\ University of Alberta, Office of Interdisciplinary Studies, 1-17 Humanities Centre, \\ Edmonton, Alberta T6G 2E5, Canada
}

\begin{abstract}
This article examines the much-debated Judean pillar figurines (JPFs), which date to the late Iron Age in the Levant and appear to be uniquely Judean artifacts. Scholarly discussion of JPFs, which has spanned a century, focuses primarily on questions of representation and use, and has contributed to the ongoing debate over the role of Asherah/asherah in monarchic Judah. The article begins with a survey of this significant discussion. Its ultimate goal, however, is to move towards a new understanding of the figurines' popularity in the eighth and seventh centuries BCE. Why did the figurines flourish in Judah during this particular period? Drawing from Antonio Gramsci's concepts of cultural hegemony and ideology, the article suggests that JPFs should be understood as part of a

* Drafts of this essay were presented at the 2010 European Association of Biblical Studies Graduate and Postgraduate Symposium, Drongen, Belgium (via video conference at the University of Alberta); and at the 2010 Pacific Northwest Regional Meeting of the American Schools of Oriental Research, Victoria, British Columbia. I would like to thank the session organizers and participants for their helpful comments. I am also grateful to Ehud Ben Zvi, Erin Darby, Raz Kletter, and the anonymous reviewer of this journal, whose critiques of earlier versions greatly improved the final product. Of course, I am solely responsible for the content herein and for any mistakes that might remain.
\end{abstract}


late Iron Age cultural discourse: the figurines represent one attempt to maintain local identity as the Neo-Assyrian empire rapidly expanded and absorbed much of the region.

Keywords: Israelite religion, Asherah, Assyrian empire, imperialism, ideology, ethnicity.

Among the most talked about and debated artifacts in the study of ancient Levantine religions are the terra cotta Judean pillar figurines (JPFs), which appear in the archaeological record as early as the tenth century $\mathrm{BCE}$ and then seem to explode in popularity during the eighth and seventh centuries. Numerous scholars have offered their thoughts on these figurines, and doctoral dissertations have focused on their typology and interpretation. ${ }^{1}$ Indeed, the scholarly discussion spans more than a century. The typical questions raised in the discussion have largely centered on what the figurines might have represented and how they might have been used: Are they depictions of a female deity such as Astarte or Asherah? Do they depict a human female? Were they used as votives, fertility charms, toys for children, or even something else? In this article,

1. E.g. W.F. Albright, 'Astarte Plaques and Figurines from Tel Beit-Mirsim', in Mélanges Syriens offerts à monsieur René Dussaud (Paris: Librarie Geuthner, 1939), pp. 107-20 (115, 120); J.B. Pritchard, Palestinian Figurines in Relation to Certain Goddesses Known through Literature (New Haven, CT: American Oriental Society, 1943; New York: Kraus Reprint, 1967); T.A. Holland, 'A Study of Palestinian Iron Age Baked Clay Figurines with Special Reference to Jerusalem Cave I', Levant 9 (1977), pp. 121-55; J.R. Engle, 'Pillar Figurines of Iron Age Israel and Asherah/Asherim' (PhD dissertation, University of Pittsburgh, 1979); R. Hestrin, 'The Lachish Ewer and the 'Asherah', IEJ 37.4 (1987), pp. 212-23 (221-22); T. Frymer-Kensky, In the Wake of the Goddesses (New York: Free Press, 1992), pp. 159-61; R. Kletter, The Judean Pillar-Figurines and the Archaeology of Asherah (BAR International Series, 636; Oxford: Tempus Reparatum, 1996), a revision of his Tel Aviv University PhD dissertation; O. Keel and C. Uehlinger, Gods, Goddesses, and Images of God in Ancient Israel (trans. T.H. Trapp; Minneapolis: Fortress Press, 1998), pp. 325-43; J.M. Hadley, The Cult of Asherah in Ancient Israel and Judah (New York: Cambridge University Press, 2000), pp. 196-205; E. Stern, Archaeology of the Land of the Bible, II (AB Reference Library; New York: Doubleday, 2001), pp. 205-11; Z. Zevit, The Religions of Ancient Israel (New York: Continuum, 2001), pp. 267-74; P.S. Johnston, 'Figuring Out Figurines', TynBul 54.2 (2003), pp. 81-104; P.R.S. Moorey, Idols of the People (Oxford: Oxford University Press, 2003), pp. 47-68; R. Byrne, 'Lie Back and Think of Judah', NEA 67.3 (2004), pp. 137-51; W. Dever, Did God Have a Wife? (Grand Rapids: Eerdmans, 2005), pp. 176-208; R. Hess, Israelite Religions (Grand Rapids: Baker Academic, 2007), pp. 308-11; C. Meyers, 'Terracottas without Texts', in R.B. Coote and N.K. Gottwald (eds.), To Break Every Yoke: Essays in Honor of Marvin L. Chaney (Sheffield: Sheffield Phoenix Press, 2007), pp. 115-30. 
rather than directly focusing on issues of representation and use, I would like to further the socio-cultural discussion of JPFs by moving towards a new theoretical understanding of their preponderance during the late Iron Age, a crucial period in the history of the ancient Near East that witnessed the rapid expansion of the Neo-Assyrian empire. Why would JPFs flourish during this period? In approaching this question, I begin with an introduction to the figurines themselves, the relevant archaeological data, and interpretations that have dominated recent scholarly debate. I then present some of my own thoughts on the figurines and their abundance in late Iron Age Judah, which, I submit, should be understood as part of a Levantine cultural discourse: the apparent popularity of JPFs marked a Judean attempt to maintain ethnic identity in the face of Assyrian imperialism.

Before proceeding, however, I would like to acknowledge that this is an extremely complex issue, one that involves a number of ongoing and significant debates in archaeology and biblical studies, many of which are highly controversial and deserve more detailed treatments than I can provide here. Recognizing these difficulties, I do not propose to have found a definitive 'solution' to the problem. My aim is to provide a concise survey and review of recent scholarship, and then hopefully to move the discussion forward by offering a new avenue from which to explore the difficult questions that these enigmatic figurines raise.

\section{JPFs: A Survey}

JPFs first appeared in archaeological excavations in Palestine in the late nineteenth century, and archaeologists have unearthed hundreds since then, with roughly half of the finds coming from Jerusalem. ${ }^{2}$ The freestanding figurines - whose bodies and pillar bases were hand-maderange in height from 13 to $16 \mathrm{~cm}$ and depict the upper body of a female, with hands holding the breasts. The heads were either hand-made (see Fig. 1) or molded (see Fig. 2). ${ }^{3}$

2. In 1996 Raz Kletter identified 854 JPFs, yet in the ensuing years even more have arisen, bringing the total to approximately 1000. See Kletter, Judean Pillar-Figurines, the most recent, thorough treatment of JPFs; also idem, 'Between Archaeology and Theology', in A. Mazar (ed.), Studies in the Archaeology of the Iron Age in Israel and Jordan (JSOTSup, 331; Sheffield: Sheffield Academic Press, 2001), pp. 179-216, a concise statement of his research.

3. Images after R. Kletter, 'Pots and Polities', BASOR 314 (1999), pp. 19-54 (23). (C) 1999 American Schools of Oriental Research. All rights reserved. Republished here by permission of the American Schools of Oriental Research. 


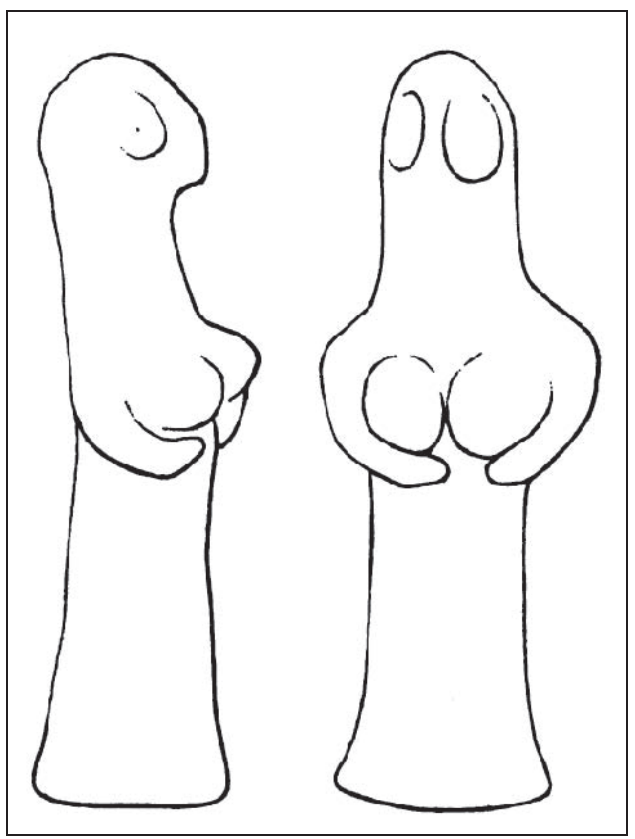

Figure 1.

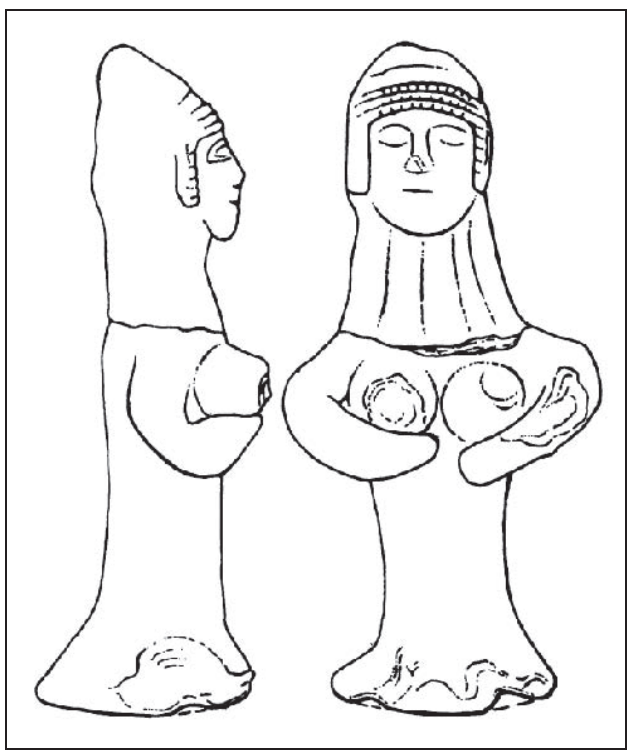

Figure 2. 
Most of the extant JPFs are broken or fragmentary; only a handful of intact samples are known. ${ }^{4}$ The figurines hail from a wide variety of find contexts, from burial sites and elite residences to common family homes and public spheres. They were pervasive in late Iron Age Judah, and their find contexts plainly show that JPFs held a prominent place in everyday Judean society. ${ }^{5}$ Despite this, establishing the chronology of JPFs has not been easy. Samples that have a secure date suggest that they emerged on a large scale in the eighth century, and usage continued throughout the seventh and into the early sixth. ${ }^{6}$ It should be noted, however, that many JPFs have been found in debris dumps, on the ground level, and in pits and building fills, that is, archaeological contexts that are not helpful in establishing chronologies. The specific timeline of JPFs thus continues to be a problem, even after a century of research. We know, nevertheless, that JPFs mostly disappeared following the Babylonian conquest and destruction of Jerusalem in 586 BCE. By the Persian period they are absent from the archaeological record. ${ }^{7}$ We can therefore date the height of JPF circulation from the eighth century to the early sixth, but establishing an

4. This has led some scholars to conclude that JPFs were deliberately broken in ritual usage (e.g. Zevit, Religions of Ancient Israel, pp. 271-72; Hess, Israelite Religions, pp. 309-10). However, Kletter, Judean Pillar-Figurines, pp. 54-56, argues against this position. His work shows that JPFs are particularly weak structures and prone to breakage, as is true for most clay figurines from the ancient world. The fact that most are broken is not exceptional (see Kletter, Judean Pillar-Figurines, p. 105, for breakage statistics). Solid evidence for widespread, intentional breaking of JPFs does not exist.

5. Curiously, supposed cultic sites have yielded only a few JPF fragments. Positively identifying such sites, however, is a problem in and of itself. In a small cave in Jerusalem (known as Cave I), a large number of JPF fragments were found along with other types of figurines and mașsee bôt, leading Kathleen Kenyon and others after her to label the cave and its attached structures as a 'cult centre' (K.M. Kenyon, Digging Up Jerusalem [London: Ernest Benn, 1974], p. 138; cf. Holland, 'Palestinian Iron Age Baked Clay Figurines', p. 136), but this identification has been a point of contention (see R.E. Tappy, 'Review of Raz Kletter, The Judean Pillar-Figurines and the Archaeology of Asherah', BASOR 310 [1998], pp. 85-89 [88]; also Moorey, Idols of the People, pp. 52-55, with additional bibliography).

6. Kletter, Judean Pillar-Figurines, pp. 40-43, counts 143 JPFs with secure chronological data (see also Kletter, Judean Pillar-Figurines, p. 94 Fig. 12): one from the ninth or eighth century; 70 from the eighth; 52 from the eighth or seventh; and 20 from the seventh/early-sixth. Earlier examples exist, but they are extremely rare-Kletter's catalog lists only ten fragments that may be dated to the tenth or ninth century.

7. Cf. E. Stern, Material Culture of the Land of the Bible in the Persian Period, 538332 B.C. (Warminster/Wiltshire: Aris \& Phillips, 1982), pp. 165-76. 
exact date for the emergence of the figurines or further sub-dividing the chronology remains difficult. ${ }^{8}$

The iconographic motif of a woman holding her breasts appears on various types of material culture and dates to at least the Neolithic period in the ancient Near East. ${ }^{9}$ Freestanding figurines with pillar bases, too, as a general form, were common throughout the Levant during the late Iron Age. The Judean variation, however, appears to have been a unique material phenomenon, localized almost exclusively within the kingdom of Judah. ${ }^{10} \mathrm{JPFs}$, compared to pillar figurines from other areas in the Levant, are rather plain in their style and ornamentation. A small percentage of JPFs contain traces of whitewash and of red, black, and yellow paints that highlight the facial features and depict simple jewelry around the neck and/or arms. ${ }^{11}$ This decoration, though, is not nearly as elaborate or fancy as the molded ornamentation found on other, contemporary figurines. For example, late Iron Age figurine heads from Philistia, Northern Israel, Transjordan, and Syria typically display molded jewelry and florid headdresses, which are absent from JPFs, and these heads often have more ornate hairstyles than the Judean samples. ${ }^{12}$ Moreover, the method of manufacturing pillar figurines in Judah generally differed from the

8. Precisely dating anything in the eighth and seventh centuries is challenging. Level III of the Judean city Lachish — which was razed by the Assyrians in 701 BCE - provides a secure benchmark for the close of the eighth century, but it is difficult to assign specific dates to materials from earlier in the eighth century. The seventh/early sixth century presents a similar problem: the destruction of Jerusalem provides evidence for $586 \mathrm{BCE}$, but points between 701 and 586 are hard to pin down. See L.L. Grabbe, Ancient Israel (London: T\&T Clark International, 2007), pp. 167-78, for a survey of the archaeology of Iron IIC Judah and additional bibliography.

9. See, for instance, the 'handmade seated female terracotta with painted details' from Chagar Bazar, Syria, c. 5500-5000 BCE (Moorey, Idols of the People, plate 1). The motif was present throughout the region.

10. Roughly 95 percent of the JPFs analyzed by Kletter came from sites within the supposed political boundaries of late Iron Age Judah. Cf. Kletter, Judean Pillar-Figurines, pp. 43-48 and p. 96 Fig. 16; also idem, 'Pots and Polities', pp. 28-32. Kletter uses the political boundaries as established by N. Na'aman, 'The Kingdom of Judah under Josiah', TA 18 (1991), pp. 3-71.

11. Kletter, Judean Pillar-Figurines, p. 50; cf. Stern, Archaeology, p. 207.

12. For examples from Philistia and Northern Israel, see Kletter, Judean PillarFigurines, p. 89 Fig. 7; for Transjordan, see Kletter, Judean Pillar-Figurines, p. 92 Fig. 10; for Syria, see Moorey, Idols of the People, plate 12. See also D.T. Sugimoto, Female Figurines with a Disk from the Southern Levant and the Formation of Monotheism (Tokyo: Keio University Press, 2008), pp. 153-62 (appendix 2b), for further examples of pillar figurines from the region. 
methods of its neighbors. The bodies of figurines from Phoenicia and Transjordan, for instance, are usually hollow (either hand- or wheelmade), as opposed to the solid, hand-made bodies of JPFs. ${ }^{13}$ That said, there are fragments of female figurines from late Iron Age Judah that share characteristics with figurines from other areas (viz. hollow bodies and applied features), but these are exceptional and few in number compared to the hundreds of typical JPFs in the archaeological record. ${ }^{14}$ On the whole, JPFs were a departure, however slight, from the pillar figurine traditions of the surrounding people groups. ${ }^{15}$

Issues of representation and use have been at the center of scholarly discussion on JPFs, primarily in an attempt to situate the figurines within the religious landscape of monarchic Judah. There are two basic answers to the question of representation, each with its own set of more specific variations: (1) JPFs represented a human female, or (2) they represented a goddess. How one handles the question of representation directly affects the question of usage.

On account of the hands-on-breasts motif, scholars often connect JPFs with motherhood and/or fertility. ${ }^{16}$ As noted, JPFs lack goddess-like adornment, and so some identify the figurines as representations of a human female, postulating that that they were used in rituals related to the concerns of motherhood. Ziony Zevit, for instance, states, '[JPFs] may have been used in rituals addressing goddesses or aspects of a goddess concerned with promoting pregnancy, lactation, and the general health of a woman's body' ${ }^{17} \mathrm{He}$ then refers to figurines, particularly those that

13. See Sugimoto, Female Figurines, pp. 26-29. He deals only with pillar figurines holding a disk, but these are representative of the general trend. 29 of the 44 figurines in his catalog (pp. 28-29, table 3) have identifiable body types. Of these, the two Judean examples are both solid; whereas 11/13 examples from Phoenicia, 3/3 examples from Northern Israel, 8/10 examples from Transjordan, and the lone example from Philistia have hollow bodies.

14. See Kletter, Judean Pillar-Figurines, pp. 31-32, 65, 246-52 (appendix 5.I-II), for discussion and catalog of the exceptional examples.

15. Cf. Frymer-Kensky, In the Wake of the Goddesses, pp. 159-61.

16. E.g. Byrne, 'Lie Back', p. 137, writes, 'The arms cradling breasts (often exaggerated) strongly suggest an intersection with fertility or maternity'. Cf. Hess, Israelite Religions, p. 310, who states, '...the large breasts might suggest lactation after birth'. These statements represent a tendency in the scholarship on JPFs to over-emphasize the size of the breasts as an iconographical feature. In fact, many of the extant JPFs do not have enlarged or exaggerated breasts (Erin Darby, personal communication).

17. Zevit, Religions of Ancient Israel, p. 273. It is difficult to parse Zevit's specific thoughts on JPFs because, in his discussion of figurines, he follows J.B. Pritchard's 
might have represented humans, as 'prayers in clay', as a sort of votive offering that worshippers would have offered to a god or goddess with hope that the deity would answer their prayers..$^{18}$ The votive figurine, as a sign and promise of human devotion, would thus stand as a representative before the deity, soliciting divine power for the human devotee. ${ }^{19}$

Still others see JPFs as depictions of a goddess. William Albright, for example, in his survey of figurines from Tell Beit Mirsim, refers to JPFs as the 'dea nutrix' of the late Iron Age. ${ }^{20}$ One should note, however, that 'nurturing goddess' and 'Mother Goddess' theories of a century ago are now widely challenged in scholarship..$^{21}$ Today many scholars view JPFs as an image of the West Semitic goddess Asherah. ${ }^{22}$ In late Bronze Age

typology, which covers a wide variety of types and conflates different styles, time periods, and manufacturing methods. Zevit even admits this typology is sometimes confusing (Religions of Ancient Israel, p. 268).

18. Zevit, Religions of Ancient Israel, p. 274. There has been some controversy over this interpretation. Dever, Did God Have a Wife?, p. 189, suggests that votives representing human females did not exist in the region. J.M. Sasson, 'On the Use of Images in Israel and the Ancient Near East', in B.M. Gittlen (ed.), Sacred Time, Sacred Place (Winona Lake, IN: Eisenbrauns, 2002), pp. 63-70 (65), however, mentions a small number of inscribed figurines from Mesopotamia that represent the human devotee, instead of the goddess or god (cf. Moorey, Idols of the People, p. 13). JPFs, though, do not have votivelike inscriptions. In a recent study on votives, C. Frevel, 'Gifts to the Gods?', in I. Cornelius and L.C. Jonker (eds), From Ebla to Stellenbosch (Wiesbaden: Harrassowitz, 2008), pp. 25-48 (29), hesitates to identify JPFs as such.

19. In this line of thought, the question remains: Would women, men, or both sexes have been the primary users of these figurines? The issue is unsettled. Meyers, 'Terracottas without Texts', p. 126, argues that 'the manipulation of JPFs was largely a femalegendered activity', whereas S.M. Olyan, 'What Do We Really Know about Women's Rites in the Israelite Family Context?', JANER 10.1 (2010), pp. 55-67 (59-62), doubts our ability to make such claims.

20. Albright, 'Astarte Plaques and Figurines', p. 120; cf. Dever, Did God Have a Wife?, p. 179. Albright and others of his generation usually linked JPFs with the goddess Astarte, who - prior to the discovery of the Ugaritic texts - was thought to be the primary goddess in the Iron Age Levant. However, few scholars today accept this identification (e.g. Stern, Archaeology, pp. 205-11, still refers to JPFs as Astarte). On Astarte and ancient Israel, see N. Wyatt, 'Astarte', in K. van der Toorn et al. (eds.), Dictionary of Deities and Demons in the Bible (Leiden: Brill; Grand Rapids: Eerdmans, 2nd edn, 1999), pp. 109-14; J. Day, Yahweh and the Gods and Goddesses of Canaan (JSOTSup, 265; Sheffield: Sheffield Academic Press, 2000), pp. 128-50.

21. See Moorey, Idols of the People, pp. 5-6; cf. Meyers, 'Terracottas without Texts', p. 118.

22. E.g. Engle, 'Pillar Figurines', pp. 50-52; Hestrin, 'The Lachish Ewer', pp. 221-22; Kletter, Judean Pillar-Figurines, pp. 80-81; Keel and Uehlinger, Gods, Goddesses, and Images of God, pp. 333-36; Dever, Did God Have a Wife?, p. 194. 
Ugaritic texts, Asherah is the consort of $\mathrm{El}$ and the mother of the West Semitic pantheon, but her place in Iron Age religious beliefs and practices is an ongoing point of debate. ${ }^{23}$ If JPFs indeed represented Asherah, devotees would have displayed the figurines, as her image, in their homes and occasionally even buried the figurines with their deceased in an attempt to elicit her power for their families. ${ }^{24}$

These two interpretive options - that JPFs represented either a human female or a goddess - are not necessarily mutually exclusive. In both cases, the figurines would have been used as a means to channel a divine power. Carol Meyers comments, 'Categorizing JPFs as magical figurines [i.e. as ritual figurines that represented the human devotee] rather than deities does not, it should be emphasized, preclude their having been used in relation to a deity'. ${ }^{25}$ Meyers further argues that identifying the deity in question is impossible without accompanying ritual texts. ${ }^{26} \mathrm{I}$ agree with Meyers on this point, but in her treatment of JPFs she intentionally avoids dealing with the biblical texts and fails to mention the Kuntillet 'Ajrud and Khirbet el-Qôm inscriptions, which do provide valuable evidence for the religious beliefs and practices of the period. I am fully aware of the problems inherent to the biblical references to Asherah/asherah. However, several of these references (e.g. $1 \mathrm{Kgs} 15.13 ; 2 \mathrm{Kgs} 21.7$ ) strongly suggest that the goddess herself was known in Iron Age Judah. And even if one

23. The debate revolves around the biblical references to Asherah/asherah, whether to the goddess herself or to a cultic object, and the ninth/eighth-century BCE inscriptions from Kuntillet 'Ajrud and Khirbet el-Qôm. The bibliography is enormous: see, e.g., W.A. Maier, 'Ašerah: Extrabiblical Evidence (HSM, 37; Atlanta: Scholars Press, 1986); S.M. Olyan, Asherah and the Cult of Yahweh in Israel (SBLMS, 34; Atlanta: Scholars Press, 1988); J. Day, 'Asherah', ABD, I, pp. 483-87; idem, Yahweh and the Gods, pp. 42-67; C. Frevel, Aschera und der Ausschliesslichkeitanspruch YHWHs (BBB, 94; 2 vols.; Weinheim: Beltz Athenäum, 1995); T. Binger, Asherah: Goddesses in Ugarit, Israel, and the Old Testament (JSOTSup, 232; Sheffield: Sheffield Academic Press, 1997); Keel and Uehlinger, Gods, Goddesses, and Images of God, pp. 210-48; J.A. Emerton, " "Yahweh and his Asherah": The Goddess or Her Cult Symbol?', VT 49 (1999), pp. 315-37; Wyatt, 'Asherah', in van der Toorn et al. (eds.), Dictionary of Deities and Demons, pp. 99-105; Hadley, The Cult of Asherah, passim; B. Becking et al., Only One God? (The Biblical Seminar, 77; London/New York: Continuum, 2001); Zevit, Religions of Ancient Israel, pp. 648-52; M.S. Smith, The Early History of God (Grand Rapids: Eerdmans, 2nd edn, 2002), pp. 108-47; S.A. Wiggins, A Reassessment of Asherah (GUS, 2; Piscataway, NJ: Gorgias Press, 2007). See also the survey of scholarship and bibliography in Smith, Early History of God, pp. xxx-xxxvi.

24. Cf. E. Bloch-Smith, 'The Cult of the Dead', JBL 111 (1992), pp. 213-24 (218-19).

25. Meyers, 'Terracottas without Texts', p. 121.

26. Meyers, 'Terracottas without Texts', p. 122. 
argues that every piece of evidence points toward a cultic symbol instead of the actual goddess, it seems unlikely that a cult symbol bearing the name of a once prominent goddess, the qnyt ilm, 'progenitress of the gods', in Ugaritic mythology, would have been completely devoid of the attributes of that goddess, or that the goddess would have been entirely forgotten in the late Iron Age - anti-Asherah/asherah polemic in the Bible is not equivalent to forgetting the goddess. Nicolas Wyatt keenly observes that '...the distinction between deity and cult object is ultimately not an ancient, but a modern one'. ${ }^{27}$ If Asherah continued to function as a first tier deity in the Iron Age, and perhaps even as Yahweh's consort, as Zevit and others argue, ${ }^{28}$ then it is likely that JPFs were associated, in some way, with her worship and veneration.

That is not to say, however, that the Asherah of the Iron Age, or any religious practice associated with her, was totally congruent with the late Bronze Age Asherah known from the Ugaritic texts. The biblical references, as well as the relevant inscriptional evidence, lack the necessary contextual data to understand precisely how the Judeans of the Iron Age would have worshipped the goddess, and what specific attributes they might have assigned to her. ${ }^{29}$ In offering interpretations of JPFs, we must be careful, too, not to reduce our understandings of the figurines to simplistic notions of 'motherhood' or 'fertility', regardless of which deity we might associate with them. Each of the West Semitic goddesses (and gods) had her own set of attributes that varied, sometimes greatly, depending upon historical and social context. ${ }^{30}$ Judeans could have implemented the figurines in a number of different ritual uses, and attached to them a number of different meanings, in different contexts.

But is this all we can say about JPFs? What more can they tell us about ancient Judah and its religious history during the eighth and seventh centuries BCE? In the discussion that follows, I would like to keep in mind two questions: first, why did this form of figurine explode in popularity in Judah during this time period? And second, how do we understand JPFs within the larger socio-cultural context of the period?

27. Wyatt, 'Asherah', p. 103; cf. Binger, Asherah, p. 109.

28. Zevit, Religions of Ancient Israel, pp. 648-52; cf. Day, Yahweh and the Gods, pp. 42-48.

29. Cf. Wiggins, Reassessment of Asherah, pp. 149-50.

30. Cf. J.G. Westenholz, 'Goddesses of the Ancient Near East 3000-1000 BC', in L. Goodison and C. Morris (eds.), Ancient Goddesses (Madison: University of Wisconsin Press, 1998), pp. 63-82. 


\section{Further Considerations:}

\section{Folk Religion and Reproductive Propaganda}

William Dever repeatedly argues two points regarding JPFs: (1) they represent Asherah, the 'mother goddess' of the Levant; and (2) they are evidence of a female-centered 'folk religion' in late Iron Age Judah that primarily worshipped Asherah. ${ }^{31}$ Dever concludes that the biblical authors, an exclusive group of privileged males, intentionally suppressed the memory of this female-centered religion in order to promote the official state religion. In Dever's interpretation, Yahwistic monotheism began to emerge in the late Judean monarchy, challenging the widespread worship of Asherah in the general populace, and creating tension between the elites of the Judean court and the practitioners of the established folk religion. Following the Babylonian conquest of $586 \mathrm{BCE}$, and into the subsequent Persian period, according to Dever, this monotheistic ideal spread and became normative among the Judean descendants. All the while, the biblical texts continued to take shape, solidifying the dominance of monotheistic worship of Yahweh.

Dever draws an important connection between JPFs and developments in Judah's religious history (see more below). However, as mentioned above, JPFs hail from modest family homes, elite residences, as well as public realms, implying that the figurines were part of life at all levels of Judean society. These find contexts do not support Dever's idea of a struggle between elites and commoners, between a dominant male culture and a suppressed female culture, at least in regard to JPFs. In addition, although his interpretation explains the disappearance of JPFs in the sixth century, it does not adequately explain why they suddenly became so widespread in the eighth century.

Ryan Byrne, contrary to Dever, contends that the find contexts, distribution patterns, and sheer quantity of the figurines require an interpretation that includes some type of monarchic support for JPF popularity and use..$^{32}$ Byrne thus asserts that JPFs emerged as part of a state ideology of gender that promoted reproduction in order to sustain Judean lineage. According to Byrne, the growing threat of the Assyrian empire, which had already wiped out the Israelite cities and towns to the north, precipitated

31. See Dever, Did God Have a Wife?, pp. 176-208 and passim; idem, What Did the Biblical Writers Know and When Did They Know It? (Grand Rapids: Eerdmans, 2001), pp. 192-98.

32. Byrne, 'Lie Back', pp. 140-41, 145. 
the propagation of this reproduction ideology in the late eighth century: the Judeans thus updated and promoted a well-known Levantine cultural form - the female figurine - to encourage sexual reproduction as the Assyrians threatened their existence. The fear became tangible, he argues, when Sennacherib's army razed a number of Judean cities and laid siege to Jerusalem in $701 \mathrm{BCE}$, which led to further JPF promulgation in Jerusalem in the seventh century.

Byrne raises a crucial point to explain the popularity of JPFs: we must consider their importance within the larger socio-cultural context. The Assyrians were a dominant force in the ancient Near Eastern world. Judah became an Assyrian vassal in 732 BCE (cf. 2 Kgs 16.7-9), and remained so until the fall of the Neo-Assyrian empire. There is no doubt that Assyria's presence influenced Judean society and culture (see more below). His interpretation of the figurines as reproductive propaganda, however, does not seem to be supported by what we know about the social practices of the region. Byrne focuses on analogies from ancient Central America, but provides none from the Near East. Judean women certainly had concerns about reproduction, a point that Byrne emphasizes. ${ }^{33}$ There is no additional evidence, however, to suggest that this concern heightened in response to Assyrian presence, nor is there another possible case of widespread fertility propaganda in the region, despite the fact that many other groups dealt with imperial conquest. Concern for lineage might have been one aspect of JPFs, ${ }^{34}$ but they did not, perforce, represent a new development in this concern. Furthermore, producing children is hardly a practical or timely response to the threat of invasion and conquest. If JPFs had risen in prominence only after Sennacherib's campaigns, as an implementation to rebuild the devastated population, then perhaps this interpretation would be more likely. But the chronology of the figurines, as problematic as it is, does not likely support the notion of a state-sponsored fertility program. JPFs were 'distinctly Judean' and had a 'uniquely Judean' meaning, to use Byrne's expressions, but we must find another theoretical model to understand their prevalence.

The Hebrew Bible does not try to hide the memory of some form of Asherah worship in late Iron Age Judah — we are told that Asa renounced his mother, Maacah, for making an 'abominable image' of Asherah

33. On concerns of reproduction and motherhood in the ancient Near East, see K. van der Toorn, From her Cradle to her Grave (trans. S.J. Denning-Bolle; Sheffield: JSOT Press, 1994), pp. 77-92; cf. Byrne, 'Lie Back', pp. 145, 148.

34. Cf. Bloch-Smith, 'The Cult of the Dead', p. 219. 
( $1 \mathrm{Kgs} 15.13$; cf. 2 Chron. 15.16), and Manasseh is said to have installed an image of the goddess in the Jerusalem temple ( $2 \mathrm{Kgs} 21.7)$. There is a general agreement, as noted above, that JPFs were associated with a divine power, and perhaps with the goddess Asherah, whether as a type of offering to the deity or as a representation of the deity. A connection between JPFs and religious culture is therefore highly likely, but it is difficult to sustain Dever's dichotomy between a Yahweh-only, monotheistic 'state' religion and an Asherah-worshipping 'folk' religion as an explanation for JPF use. ${ }^{35}$ There is nothing to suggest that Asherah worship was more popular among common 'folk' than among the elite at this time. Again, the biblical accounts do not state otherwise: each of the Judean monarchs of the Neo-Assyrian period, with the exception of Hezekiah and Josiah, are said to have been supportive, or at least tolerant, of polytheistic religious practice (cf. 2 Kgs 16-23). Judah's religion in the eighth and seventh centuries tended towards monolatrous, aniconic worship of Yahweh, whom the Judeans saw as the supreme deity, but this tendency did not necessarily exclude worship of Asherah and other deities. ${ }^{36}$ JPFs were part of the Judean religious culture, but we have to look elsewhere to understand how they fit into the picture. Along these lines, I also find it hard to follow Byrne's interpretation, which - in

35. For recent discussions of official religion and family religion in ancient Israel, see the essays by R. Albertz ('Family Religion in Ancient Israel and its Surroundings') and S.M. Olyan ('Family Religion in Israel and the Wider Levant of the First Millennium BCE'), in J. Bodel and S.M. Olyan (eds.), Household and Family Religion in Antiquity (Malden, MA: Blackwell, 2008), pp. 89-112 and 113-126, respectively; also the recent work by F. Stavrakopoulou, “"Popular” Religion and “Official” Religion', in F. Stavrakopoulou and J. Barton (eds.), Religious Diversity in Ancient Israel and Judah (London: T\&T Clark International, 2010), pp. 37-58, who provides a thorough critique of this problematic dichotomy (see esp. pp. 43-44, for her analysis of Dever's position).

36. See R. Albertz, A History of Israelite Religion in the Old Testament Period, I (trans. J. Bowden; OTL; Louisville, KY: Westminster/John Knox Press, 1994), pp. 18095; T.N.D. Mettinger, No Graven Image? (ConBOT, 42; Stockholm: Almqvist \& Wiksell, 1995), pp. 135-97; idem, 'Israelite Aniconism', in K. van der Toorn (ed.), The Image and the Book (CBET, 21; Leuven: Peeters, 1997), pp. 178-93 (cf. T. Ornan, The Triumph of the Symbol [OBO, 213; Fribourg: Academic Press; Göttingen: Vandenhoeck \& Ruprecht, 2005], who shows that aniconic tendencies were not limited to West Semitic traditionsthey were evident in Mesopotamia as well); Keel and Uehlinger, Gods, Goddesses, and Images of God, pp. 283-372, 402-403 (cf. C. Uehlinger, 'Anthropomorphic Cult Statuary', in van der Toorn [ed.], The Image and the Book, pp. 129-39; idem, 'Was There a Cult Reform under King Josiah?', in L.L. Grabbe [ed.], Good Kings and Bad Kings [London: T\&T Clark International, 2007], pp. 279-316); also Zevit, Religions of Ancient Israel, pp. 648-52. 
addition to the issues raised above - does not incorporate any detailed discussion of religion into its conclusions. I do, however, agree with Byrne's proposal that JPFs reflected a response to the expansion of the Neo-Assyrian empire. This response, I submit, was a Judean attempt to maintain ethnic identity, not family lineage.

\section{Facing Empire}

Supporting an argument for reproduction ideology is difficult to do, but religious ideology was abundant in the ancient Near East. Although the Assyrians probably did not officially impose their religion upon vassal states, ${ }^{37}$ the Assyrian vassal treaties and imperial propaganda of the eighth and seventh centuries were laden with theological language and no doubt presented a challenge to Judean culture and religion. Esarhaddon's vassal treaty, for example, reads, 'If you sin against this treaty which [your] lord Esarhaddon, king of Assyria, has established with you....may Ashur, father of the gods, strike you down with his fierce weapons'.$^{38}$ The text goes on to describe at great length the many horrible things that the Assyrian deities will do to the vassal if it does not comply with the demands of the treaty. Assyrian imperial propaganda, which proclaimed the supremacy of Assyria's king and his deities, directly confronted Judah and the rest of the Levant in the eighth century BCE. Questions of how to deal with Assyrian domination - politically, socially, and theologically — are present throughout biblical literature, and even influenced the formation of some biblical texts. ${ }^{39}$ The biblical accounts of Sennacherib's besieging of Jerusalem (2 Kgs 18-19; Isa. 36-37; cf. 2 Chron. 32), for instance, display a strong awareness of the problem, and suggest that Judean literati

37. Cf. M. Cogan, Imperialism and Religion (SBLMS, 19; Missoula, MT: Scholars Press, 1974), pp. 111-15; idem, 'Judah under Assyrian Hegemony', JBL 112 (1993), pp. 403-14; pace S. W. Holloway, A ̌̌šur is King! Aššur is King! Religion in the Exercise of Power in the Neo-Assyrian Empire (CHANE, 10; Leiden: Brill, 2001).

38. ANET, p. 539. For additional examples, see S. Parpola and K. Watanabe, NeoAssyrian Treaties and Loyalty Oaths (SAA, 2; Helsinki: University of Helsinki Press, 1988).

39. Cf. B. Halpern, 'Jerusalem and the Lineages', in B. Halpern and D.W. Hobson (eds.), Law and Ideology in Monarchic Israel (JSOTSup, 124; Sheffield: Sheffield Academic Press, 1991), pp. 11-107 (59-77), who discusses Judah's response to Assyria, using the biblical texts as his primary evidence; also E. Bloch-Smith, 'Life in Judah from the Perspective of the Dead', NEA 65.2 (2002), pp. 120-30. For examples of Assyrian influence on the formation of biblical literature, see T. Römer, The So-Called Deuteronomistic History (London: T\&T Clark International, 2007), pp. 67-106. 
began dealing with these questions in writing as early as the seventh century. ${ }^{40}$ Moreover, Proto-Isaiah evinces a deep knowledge of Assyrian imperial language and even uses it as polemic against the Assyrians. ${ }^{41}$ The problem of Assyrian domination held a prominent place in Judean intellectual discourse for several centuries thereafter..$^{42}$

The ideological interaction between Assyria and its vassals provides a good example of what Antonio Gramsci calls an 'educational relationship' between competing national or international cultural forces. ${ }^{43}$ Ideologies, both internal and external to a society, are constantly communicating with each other, challenging and maintaining a society's internal cultural hegemony. That which is culturally hegemonic, according to Gramsci's thinking, contributes to and informs the taken-for-granted worldview within a society, facilitating the internal power structures of society. Cultural hegemony is not something consciously imposed upon a society from outside forces; it is the unconscious aspect of culture that governs and informs cultural practice within the society itself. ${ }^{44}$ Ideology, by contrast, brings the culturally hegemonic to light, questioning its

40. Cf. P. Machinist, 'The Rab Šāqēh at the Wall of Jerusalem', HS 41 (2000), pp. 151-68 (166), who states, ' $\ldots$ [the accounts] belong to a literary process that began within living experience of the Neo-Assyrian empire, and so well before its collapse in the years 614-609 B.C.E'. See E. Ben Zvi, 'Who Wrote the Speech of Rabshakeh and When?', JBL 109 (1990), pp. 79-92, for another view of these texts.

41. Cf. P. Machinist, 'Assyria and Its Image in the First Isaiah', JAOS 103.4 (1983), pp. 719-37.

42. This raises the question of Assyria's physical presence in Judah prior to and following Sennacherib's campaigns. N. Na'aman, 'An Assyrian Residence at Ramat Rahel?', TA 28 (2001), pp. 260-80, asserts that Ramat Rahel, very near to Jerusalem, functioned as an Assyrian administration center in the eighth and seventh centuries (interestingly, eleven JPF fragments have been found at the site). G. Barkay interprets the site as a Judean royal residence (cited in A.G. Vaughn, Theology, History, and Archaeology in the Chronicler's Account of Hezekiah [Atlanta: Scholars Press, 1999], pp. 39-40). Regardless of whether or not the Assyrians kept officials in Judah, it is clear that Assyrian imperialism had a lasting and meaningful impact on the Judeans and their culture.

43. A. Gramsci, Selections from the Prison Notebooks (trans. and ed. Q. Hoare and G. N. Smith; New York: International Publishers, 1971), pp. 348-51. Gramsci was interested in politics and society in the context of the modern nation-state, not the ancient world, but some of his thoughts, which have influenced a number of historians and anthropologists, are heuristically helpful here. See J. Comaroff and J. Comaroff, Of Revelation and Revolution, I (Chicago/London: University of Chicago Press, 1991), pp. 18-32, who offer an insightful reading of Gramsci from an anthropological perspective.

44. In many ways, Gramsci's ideas about culture prefigure the theories of later poststructuralist thinkers such as Michel Foucault and Pierre Bourdieu. See Comaroff and Comaroff, Revelation and Revolution, pp. 20, 22-24. 
taken-for-granted status within the society. ${ }^{45}$ The ideological may take many cultural forms, but its content is always communicable, recognizable by the society as something different from normative cultural experience. Ideology and cultural hegemony thus stand at extreme ends of a cultural spectrum, as it were: ideology as conscious cultural communication, and hegemony as the unconscious cultural norms or worldview. Over time, as a society encounters new ideologies from within and from without, cultural forms and practices - and the symbolic meanings attached to them - oscillate between these two extremes in the cultural field. The discourse between ideology and cultural hegemony is continuously advancing, preserving old ideologies and fusing them with new ones, creating new expressions of culture and reformulating that which is culturally hegemonic, and that which is ideological, within the society.

Gramsci's ideas are particularly helpful for thinking about interactions between imperial or colonial forces and their subjects, and the development of material culture within these contexts. Imperialism intrinsically introduces new ideologies to subjected societies and challenges the internal cultural hegemony of those societies. These interactions in imperial contexts naturally lead to reformulations of normative cultural practices and forms. Jean and John Comaroff comment, 'Because the liminal space between the hegemonic and the ideological, consciousness and unconsciousness, is also the area in which new relations are forged between form and content, it is likely to be the source of the poetic imagination, the creative, the innovative'. ${ }^{46}$ In these types of confrontational contexts, in which distinct societies interact and new ideologies are introduced, cultural innovations can become ethnic markers, means by which the subjugated society defines itself in relation to others, attempts to maintain its identity, and structures its interactions with others. ${ }^{47}$

45. For Gramsci, ideology does not necessarily carry the negative connotation that most Marxist thinkers have assigned to it. Cf. Gramsci, Selections, pp. 375-77.

46. Comaroff and Comaroff, Revelation and Revolution, p. 30.

47. On ethnicity in general, see the classic introduction by F. Barth, in F. Barth (ed.), Ethnic Groups and Boundaries (Boston: Little, Brown \& Company, 1969), pp. 9-38; and the collection of works in J. Hutchinson and A.D. Smith (eds.), Ethnicity (Oxford: Oxford University Press, 1996). On ethnicity in ancient Israel and in the Bible, see, e.g., K. Sparks, Ethnicity and Identity in Ancient Israel (Winona Lake, IN: Eisenbrauns, 1998); M.G. Brett (ed.), Ethnicity and the Bible (Leiden: Brill Academic, 2002); A.E. Killebrew, Biblical Peoples and Ethnicity (Atlanta: Society of Biblical Literature, 2005); A. Faust, Israel's Ethnogenesis (London: Equinox, 2006); also the survey of scholarship and extensive bibliography in J.C. Miller, 'Ethnicity and the Hebrew Bible', CBR 6.2 (2008), pp. 170-213. 
Within the midst of the confrontation between Assyria and its Levantine subjects, we find the large-scale emergence of the JPF, an artifact that appears to have been an important aspect of Judean religious culture. Religion, along with language, is one of the most striking markers of ethnic identity, and often becomes a rallying point for ethnic survival. ${ }^{48}$ Being subsumed under an imperial system presented a serious challenge to Judah's identity and to its internal cultural hegemony, its taken-forgranted worldview and cultural norms. I suggest, then, that in the second half of the eighth century, in response to spreading Assyrian imperialism, the Judeans popularized their variation of the pillar figurine in one attempt to sustain particular features of their religious and cultural heritage, thus attempting to maintain their ethnic boundaries and protect elements of their social identity. ${ }^{49}$ As a result, JPFs materialized on a large scale and became a uniquely Judean cultural marker. This expression of identity helped define the people of Judah in relation to Assyria's imperialism and in relation to their neighbors, who also found themselves under Assyrian rule. JPFs therefore reflected an attempt by the Judean populace to maintain ethnic identity on the periphery of the Assyrian empire, yet this attempt also created a local cultural phenomenon: the figurines exploded in popularity like never before, contributing to an ongoing cultural discourse within the Levant. ${ }^{50}$ Thus, one might think of the periphery (Judah) resisting the worldview of the center (Assyria), but the discourse also involved other peripheral identities. 'Resistance' or 'rebellion' in imperial contexts is never simply a case of a weaker political or social class revolting against a more powerful one; such historical moments involve complex social discourses as well as struggles over local community institutions. ${ }^{51}$

48. See the section on ethnicity, religion, and language in Hutchinson and Smith (eds.), Ethnicity, pp. 187-235.

49. Focusing on social boundaries, which may or may not coincide with territorial boundaries, is key to recognizing ethnic differentiation. Cf. Barth, Ethnic Groups, pp. 1516; M.T. Stark (ed.), The Archaeology of Social Boundaries (Washington, DC: Smithsonian Institution Press, 1998).

50. For further discussion on religious diversity in the southern Levant, see the recent essay by J.M. Hutton, 'Southern, Northern and Transjordanian Perspectives', in Stavrakopoulou and Barton (eds.), Religious Diversity in Ancient Israel and Judah, pp. 149-74. Hutton, though, deliberately chooses not to deal with pillar figurines in this essay.

51. Cf. J. Glassman, Feasts and Riot (Portsmouth, NH: Heinemann, 1995), pp. 1-25, who also utilizes Gramsci's thoughts in his research. 
The style of JPFs, or lack thereof, certainly lends itself to this interpretation. Patterns of similarity and difference in style and decoration can contribute greatly to our knowledge of an item's meaning in a specific cultural context..$^{52}$ In particular, in some cases stylistic differences can be an indicator of ethnic differentiation. ${ }^{53}$ Representations of goddesses and female figures had a long history in the ancient Near Eastern world, and variations of pillar figurines existed throughout the Levant. If the figurines indeed represented Asherah, or some other goddess, then this Judean version depicted the deity in less prominent fashion than usual. If they were meant to depict a human female, offered to the goddess as a type of votive, then JPFs lack the typical features of other female examples. As already stated, JPFs were a slight departure from the iconographic traditions of the region. The horse-and-rider figurines from the southern Levant, which also date to the eighth and seventh centuries, display a similar stylistic trend. Although all the horse-and-rider figurines are similar in general iconography, there is a clear differentiation of detail and style between those found in Judah and those found in neighboring Transjordan and Phoenicia. ${ }^{54}$ In the eighth and seventh centuries, Judah, as an ethnos, was maintaining boundaries between itself and its neighbors - and vice versa - and the imperial force of Assyria provided a catalyst.

Other cultural developments in the Levant, too, promote this way of thinking. During the late Iron Age - as the Neo-Assyrian empire expanded and Aramaic became the primary diplomatic language of the Near Eastuniquely Ammonite, Moabite, and Edomite scripts developed. ${ }^{55}$ These are distinguishable from those of Israel, Judah, and Phoenicia, and may be thought of as expressions of local identities. Moreover, there exists a small number of artifacts from this period, in addition to JPFs and horseand-rider figurines, that one may classify as distinctly Judean, for example, the lmlk seal impressions and the rosette stamps, found abundantly on Judean pottery. ${ }^{56}$ These symbols were probably instituted by the Judean monarchy under Assyrian subjugation (the lmlk impressions by Hezekiah

52. See I. Hodder and S. Hutson, Reading the Past (Cambridge: Cambridge University Press, 3rd edn, 2002), pp. 183-91.

53. Cf. Faust, Israel's Ethnogenesis, p. 43.

54. Cf. Kletter, 'Pots and Polities', pp. 38-40, with additional bibliography.

55. Cf. J. Naveh, 'Aramaic Script', $A B D$, I, pp. 342-45 (344); A. Lemaire, 'Epigraphy, Transjordanian’, $A B D$, II, pp. 561-68 (561).

56. See Kletter, 'Pots and Polities', pp. 28-40. 
or perhaps Ahaz and, subsequently, the rosettes sometime during the late seventh century, perhaps by Josiah or Jehoiakim). ${ }^{57}$ Their solar iconography was most likely connected with Judah's chief deity, Yahweh, and his divine powers, as Glen Taylor and others have shown. ${ }^{58}$ The seals and stamps, therefore, became symbols of political and religious identity at moments in history when the Judeans were presented with unique external challenges, and they further evidence the 'educational relationship' between the culture of Judah and that of its neighbors. Indeed, these markers were so successful as Judean symbols that Raz Kletter uses their geographical distribution, alongside that of JPFs, to assess the putative political boundaries of the Judean kingdom during the late Iron Age. ${ }^{59}$ The aforementioned examples help bring the entire picture into focus: Assyrian imperialism had a deep impact on Judean and Levantine society; from the level of the common person to that of the royal elite, there is evidence of attempts to maintain and assert local identity within the empire.

As mentioned above, roughly half of the JPFs (over four hundred) were found in Jerusalem, the Judean capital. This raises the question of statesupport. The monarchy undoubtedly knew about JPFs, and perhaps even utilized them. In the Comaroffs' Gramscian way of thinking (see above), however, one might understand the prevalence of JPFs as the product of an organic, grass-roots movement; if cultural innovation characteristically arises in the realm between consciousness and unconsciousness, between

57. On the lmlk seals, see, e.g., Vaughn, Theology, History, and Archaeology, pp. 81167; O. Lipschits, O. Sergi, and I. Koch, 'Royal Judahite Jar Handles', TA 37 (2010), pp. 3-32. For rosettes, see J.M. Cahill, 'Rosette Stamp Seal Impressions from Ancient Judah', IEJ 45 (1995), pp. 230-52. Kletter, 'Pots and Polities', pp. 36-37, however, questions the royal nature of the latter.

58. J.G. Taylor, Yahweh and the Sun (JSOTSup, 111; Sheffield: JSOT Press, 1993), pp. 40-58, 261; cf. Keel and Uehlinger, Gods, Goddesses, and Images of God, pp. 274-77, 353-54. On solar language in the Bible and its relation to Yahweh, see M.S. Smith, 'The Near Eastern Background of Solar Language for Yahweh’, JBL 109 (1990), pp. 29-39; idem, Early History of God, pp. 148-59. For a discussion of male figurines and possible connections with Yahweh, see R.S. Hendel, 'Aniconism and Anthropomorphism in Ancient Israel', in van der Toorn (ed.), The Image and the Book, pp. 205-28 (212-18). Figurines of male deities, unlike JPFs, were exceedingly rare in Iron Age Israel and Judah. If Judeans were indeed becoming increasingly aniconic in their worship of Yahweh, then it makes sense that his divine powers would be expressed in astral symbolism rather than in anthropomorphic figurines.

59. Cf. Kletter, 'Pots and Polities', pp. 19-54. 
explicit ideology and taken-for-granted cultural hegemony, then it is unlikely that an official, state-supported program was the impetus for the figurines' popularity. ${ }^{60}$

One final point: although we may think of JPFs' rise in popularity as an example of Judah maintaining ethnicity vis-à-vis its neighbors, this is, of course, not true for all elements of Judean culture in the eighth and seventh centuries. Judah often shared cultural forms and practices with its neighbors (e.g. aspects of the solar iconography noted above). As I emphasized at the outset, this is an extremely complex issue. Culture is never static; it continuously moves forward, resisting, adopting, and fusing ideologies to reformulate worldviews. As Keel and Uehlinger show in great detail, the material culture of Judah and Israel frequently confronted new influences, from within and without, and as a result new forms of cultural expression emerged ${ }^{61}$ The ways that people react to unfamiliar cultural forces, especially in imperial or colonial contexts, are never uniform or predictable, as we have learned in recent years. The impact of Assyrian imperialism on Judah (and the whole of the Levant) was multifaceted and had a diverse effect on Judean culture, society, and ethnic identity. The Judean pillar figurines were only one statement in this complex discourse.

60. Also, petrographic analyses and ethnographic analogues do not seem to corroborate the idea of a state-supported program (Erin Darby, personal communication).

61. See Keel and Uehlinger, Gods, Goddesses, and Images of God, passim. 